\section{Antitubercular Activity of some 8-Hydroxyquinoline Derivatives}

THE well-known antiseptic properties of 8-hydroxyquinoline, and particularly experiments on the use of this compound as an antitubercular agent ${ }^{1}$, led one of us (T. U.) to prepare a few derivatives of 8-hydroxyquinoline, in order to examine their activity against Mycobacterium tuberculosis.

One of the products tested, $T 28$, proved to be particularly interesting due to its activity both in vitro and in vivo and to its low toxicity. The product was prepared by the action of sodium hydrogen sulphite on 5-nitroso 8 -hydroxyquinoline. It proved to be monohydrate of $\mathrm{N}$-sulpho- $\mathrm{N}$-[5-quinolyl-8hydroxy]-hydroxylamine (I), so far unknown in the literature.

A detailed description of the method of preparation and the proof of the structure will be reported else. wher $\Theta^{2}$. On boiling with concentrated hydrochloric acid, (I) was hydrolysed and, surprisingly enough, chlorinated, to yield the hydrochloride of 6.7-dichloro-5.8-dihydroxyquinoline (II).
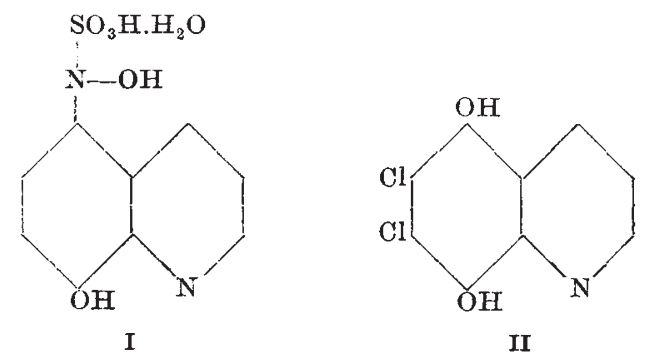

The substance (II) also possesses strong antitubercular action in vitro, but experiments in vivo have not been carried out because of its high toxicity.

The other 8-hydroxyquinoline derivatives tested were: 5-amino-(III)- and 5.7-diamino-(IV)-quinoline. They were prepared in a new way - by reduction with sodium hydrosulphite of 5-nitroso- and 5.7-dinitro-8hydroxyquinoline respectively. 5-Sulpho-8-hydroxyquinoline (sodium salt) (V) and 8-hydroxyquinoline sulphate (VI) were also tested and used as a standard.

The bacteriostatic concentrations were determined in vitro in Youmans's medium against six strains of saprophytic mycobacteria. Limits obtained for different strains are shown in Table 1.

Table 1

\begin{tabular}{|c|c|c|c|c|c|c|}
\hline Sulustance & $\begin{array}{c}\text { T.2s } \\
(\mathrm{I})\end{array}$ & $(\mathrm{II})$ & $(\mathrm{III})$ & $(\mathrm{IV})$ & $(\mathrm{V})$ & $(\mathrm{VI})$ \\
\hline $\begin{array}{c}\text { Bacteriostatic con- } \\
\text { centrations } \\
\text { (mgm. per 100 } \\
\text { ml.) }\end{array}$ & $5-30$ & 2 & $2 \cdot 5-5$ & $2 \cdot 5-15$ & $125-250$ & $2 \cdot 5-5$ \\
\hline
\end{tabular}

Table 2 shows the toxicity to rats of substances (I) $-(\mathrm{V})$.

Table 2. LethaL DOSE (GM. PER KGM. BODY-WhIGHT)

\begin{tabular}{|c|c|c|c|}
\hline Substance & $\begin{array}{c}\text { Intravenous } \\
\text { injection }\end{array}$ & $\begin{array}{c}\text { Subcutaneous } \\
\text { injection }\end{array}$ & per os \\
\hline $\begin{array}{rr}\text { (I) } \\
\text { (II) } \\
\text { (III) } \\
\text { (IV) } \\
\text { (V) }\end{array}$ & $\begin{array}{l}1 \cdot 0 \\
0 \cdot 02 \\
0 \cdot 06 \\
0 \cdot 02 \\
1 \cdot 2\end{array}$ & $\begin{array}{l}1 \cdot 5 \\
0 \cdot 11 \\
0 \cdot 03 \\
2 \cdot 0\end{array}$ & $\begin{array}{l}\text { c. } 3 \cdot 0 \\
\text { c. } \overline{0} \cdot 5 \\
0 \cdot 5 \\
\text { c. } 5 \cdot 0\end{array}$ \\
\hline
\end{tabular}

The experiments carried out with Langendorf's rat's heart preparation showed that $T^{\prime} 28$ has no influence on the heart and coronary flow when $0.1 \mathrm{ml}$. of 5 per cent solution was administered. When given intravenously to a rabbit in doses of $50 \mathrm{mgm}$. per kgm. body-weight it caused only a small and temporary increase of the blood pressure. An injection of $50 \mathrm{mgm}$. per kgm. body-weight produced a fall of the sugar level by c. 20 per cent, lasting for $4 \mathrm{hr}$. Also only a very insignificant influence was observed on the peristaltic concentrations of the isolated rabbit's small intestine in a 0.1 per cent solution. No hæmolysis of rabbit red cells in vitro was observed.

Experiments in vivo were carried out by using guinea pigs (c. $500 \mathrm{gm}$.) inoculated intraperitoneally with $0.1 \mathrm{mgm}$. of Mycobacterium tuberculosis $\left(\mathrm{H}_{37} R v\right.$ strain). The results are shown in Table 3.

Table 3

\begin{tabular}{|l|c|c|c|c|c|}
\hline & $\begin{array}{c}\text { No. of } \\
\text { animals }\end{array}$ & $\begin{array}{c}\text { Daily dose } \\
\text { (mgm. per } \\
\text { animal, } \\
\text { subcut.) }\end{array}$ & $\begin{array}{c}\text { Mortal- } \\
\text { ity (per } \\
\text { cent) }\end{array}$ & $\begin{array}{c}\text { Average } \\
\text { tuber. } \\
\text { index }\end{array}$ & $\begin{array}{c}\text { Average } \\
\text { survival } \\
\text { time } \\
\text { (days) }\end{array}$ \\
\hline $\begin{array}{l}\text { Streptomycin } \\
T 28\end{array}$ & 20 & 8 & 10 & 57 & $\mathbf{8 4 \cdot 4}$ \\
Control & 20 & 10 & 40 & 64 & $76 \cdot 1$ \\
20 & - & 90 & 100 & $47 \cdot 2$ \\
\hline
\end{tabular}

Treatment with $T$ ' 28 and streptomycin started one week after inoculation.

The animals were treated for $\mathbf{4 2}$ days. They were then observed for a further 36 days; all survivors were killed, and the extent of tuberculous involve. ment was noted and rated.

Experiments on the clinical use of $T 28$ are being commenced.

Institute of Tuberculosis, and Department of Chemistry,

Institute of Technology, Warsaw.

Department of Bacteriology,

S. SLOPEK

Silesian Medical Academy.

Department of Pharmacology, Medical Academy,

Warsaw.

Feb. 21.

${ }^{1}$ McElroy, Lancet, 1408 (1910). Bidault, Urbain, C.R. Soc. Biol., 99, 461 (1928). Albert, A., Rubbo, S. D., Goldacre, J. R., and Balfour, B. G, Brit. J. Exp. Path., 28, 2579 (1948). Binswanger, L. A."
Erlenmeyer, H., Sorkin, E., and Suter, E., Helv., 31, 1975 (1948). ${ }^{2}$ Roczniki Chemii (Warsaw) (to be published).

\section{Preparation of the Optical Forms of Tris- Acetylacetone Cobalt III}

IN an earlier communication ${ }^{1}$, a number of experiments were described leading to the conclusion that the activities of enantiomeric ions could be changed to a different extent by the addition of an electrolyte containing an optically active anion or cation. In order to demonstrate the general applicability of this principle, we have sought to resolve a typical nonelectrolytic complex salt without salt-forming groups. The peripheral atoms in the tris-acetylacetone cobalt III complex probably carry a slight negative charge, and hence negative or anionic asymmetrical fields are associated with the antipodal forms. The maximum differential interaction in solution is to be 